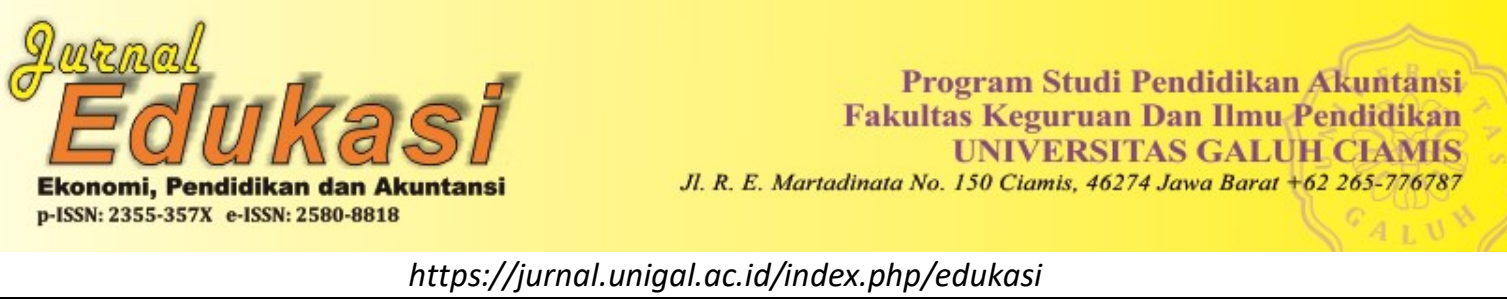

\title{
PERBEDAAN METODE PEMBELAJARAN ROLE PLAYING DENGAN METODE BRAINSTORMING DALAM PEMBELAJARAN AKUNTANSI
}

\author{
Oleh: \\ Ilah ${ }^{1}$, Risky Nurmayanti ${ }^{2}$ \\ Prodi Pendidikan Akuntansi FKIP Universitas Galuh, Indonesia \\ Jalan RE Martadinata No 150 Ciamis \\ Email: ilahmulyadi.im@gmail.com \\ Sejarah Artikel: Diterima Maret 2020, Disetujui April 2020, Dipublikasikan Juni 2020
}

\begin{abstract}
ABSTRAK
Penelitian ini dilatarbelakangi hasil belajar siswa yang kurang optimal di kelas XI Akuntansi SMK Negeri 3 Banjar. Hasil kurang memuaskan terlihat pada Kompetensi Dasar Akuntansi Perusahaan Dagang. Salah satu penyebabnya adalah kurangtepatnya penggunaan model pembelajaran. Menyikapi permasalahan tersebut, peneliti mencoba melakukan eksperimen, yakni menerapkan metode Role Playing dan metode Brainstorming. Metode penelitian menggunakan metode eksperimen dengan design Nonequivalent Control Group Design. Objek penelitian ini terdiri atas dua kelas, yakni kelas eksperimen sebanyak 15 orang dan kelas kontrol sebanyak 14 orang. Teknik pengumpulan data menggunakan teknik observasi dan teknik tes. Pengolahan data menggunakan rumus Uji-t. Hasil analisis menyatakan bahwa hasil pembelajaran dengan menggunakan model Role Playing lebih unggul dibandingkan dengan hasil belajar siswa dengan menggunakan model Brainstorming.
\end{abstract}

Kata Kunci: Model Pembelajaran, Role Playing, Brainstorming

\section{ABSTRACT}

This research is backed by the low learning outcomes of students in class XI accounting SMK Negeri 3 Banjar. Less satisfactory results are seen in the basic competency of accounting company. One of the reasons is precisely the use of learning models. Addressing the issue, researchers are attempting to experiment, which is implementing Role Playing learning methods and Brainstorming learning methods. The research method used is the experimental method with the design of Nonequivalent Control Group Design. The object in this study consisted of two classes, the experimental class as many as 15 people and a control class of 14 people. Data collection techniques using observation techniques and test techniques. Data processing Using test-t formula. The results of the analysis stated that learning outcomes using the Role Playing learning model was superior to the learning outcomes of learners using the Brainstorming model.

Keywords: learning Model, Role Playing, Brainstorming

\section{PENDAHULUAN}

Hasil belajar yang diterima setelah proses pembelajaran merupakan hal yang sangat penting bagi siswa. Hasil belajar ini dapat berupa pengetahuan, keterampilan, dan juga kemampuan-kemampuan. "Hasil belajar adalah kemampuan yang dimiliki siswa setelah menerima pengalaman belajarnya" (Sudjana 2016). Sedangkan menurut pendapat lain
Kurniawan (2014:8) mengemukakan bahwa hasil belajar merupakan perubahan tingkah laku yang relative permanen pada individu, yang ditunjukan oleh adanya kemampuan bereaksi, dimana kemampuan bereaksi itu akan terbentuk dengan kuat jika ada pengulangan dan penguatan.

Dalam proses belajar dilandasi beberapa teori belajar yang menuntun terbentuknya 
kondisi untuk belajar seperti yang dijelaskan oleh Mulyono (2016:92) diantaranya (1) teori behaviorisme, (2) teori belajar kognitif, (3) teori belajar gestalt, (4) teori belajar kontruktivisme, dan (5) teori belajar sosial.

Untuk mengetahui hasil belajar dilakukan pengukuran prestasi belajar siswa yaitu dengan menggunakan alat ukur (test). Menurut Arikunto (2012:47) menyatakan bahwa tes adalah suatu alat untuk pengumpul informasi yang bersifat resmi.

Pelaksanaan pengukuran hasil belajar dilakukan melalui tiga cara yaitu tes lisan, tes tertulis, dan tes perbuatan. Tes tertulis dilakukan dengan mengajukan butir pertanyaan secara tertulis kepada siswa, pada tes lisan dilakukan dengan cara melakukan tanya jawab antara guru dan siswa, sedangkan tes perbuatan dipergunakan untuk mengetahui tingkatan kemampuan yang bersifat keterampilan dimana penilaiannya dilakukana terhadap proses dalam menyelesaikan tugas dan hasil akhir yang dicapai siswa.

Kenyataan di pembelajaran tidak semua siswa mampu memperoleh hasil belajar yang diharapkan atau dapat mencapai nilai di atas Kriteria Ketuntasan Minimal (KKM) artinya masih ada siswa yang masih memperoleh nilai di bawah KKM.

Banyak faktor yang mempengaruhi kurang maksimalnya hasil belajar siswa diantaranya adalah penggunaan model dan metode pembelajaran, menurut Jamil (2013:143) menjelaskan bahwa model Pembelajaran yakni suatu kerangka, rencana atau pola yang menggambarkan prosedur dalam mengorganisasikan pelaksanaan pembelajaran maupun kegiatan siswa dan dapat dijadikan petunjuk guru mengajar di depan kelas". Sedangkan Darmadi (2010:43) menyatakan bahwa metode pembelajaran yakni cara yang harus digunakan untuk mencapai tujuan pembelajaran.

Pembelajaran yang dilaksanakan disekolah biasanya hanya bersifat konvensional artinya proses pembelajaran didominasi oleh guru sementara siswa cenderung pasif. Siswa yang pasif berpengaruh pada kurangnya keterlibatan dalam mengikuti pembelajaran, rendahnya kemampuan sosial antar guru dan siswa maupun antar siswa lainnya dan kurangnya percaya diri siswa dalam mengungkapkan pendapat, sehingga hal tersebut dapat menurunkan hasil belajar siswa.

Dalam hal ini guru harus kreatif untuk membuat siswa menjadi aktif dalam proses pembelajaran, salah satu upaya yang bisa dilakukan adalah dengan merubah metode pembelajaran, metode pembelajaran yang dipilih haruslah yang bersifat inovatif, interaktif, dan menyenangkan.

Penggunaan metode pembelajaran tersebut diharapkan dapat mempengaruhi peningkatan hasil belajar siswa yaitu dengan penggunaan metode yang dapat membuat adanya interaksi antara guru dengan siswa dan antara siswa lainnya dan adanya timbal balik dari siswa dengan guru, sehingga tujuan pembelajaran dapat tercapai.

Berdasarkan latar belakang penelitian tersebut, penulis tertarik untuk melakukan penelitian sehubungan dengan pencapaian hasil belajar siswa pada mata pelajaran akuntansi di kelas XI AKL SMK Negeri 3 Banjar. Sebagai data awal, penulis sajikan hasil ulangan mata pelajaran akuntansi siswa kelas XI AKL SMK Negeri 3 Banjar.

Tabel 1

Ketuntasan Mata Pelajaran Akuntansi Kelas XI AKL SMK Negeri 3 Banjar

\begin{tabular}{ccccc} 
Kelas & Jlm Peserta & Tuntas & Belum Tuntas & \% \\
\hline XI AKL 1 & 15 & 10 & 5 & $33,33 \%$ \\
XI AKL 2 & 14 & 10 & 4 & $28,57 \%$ \\
XI AKL 3 & 17 & 9 & 8 & $47,06 \%$ \\
& 46 & 29 & 17 & $36,96 \%$
\end{tabular}

Data tersebut menunjukan kurang maksimalnya hasil belajar siswa karena belum mencapai daya serap minimal $85 \%$ Kriteria Ketuntasan Minimal (KKM). KKM Nilai ratarata Mata Pelajaran Akuntansi di SMK Negeri 3 Banjar sebesar 75. Dengan demikian, guru harus bersedia dan mampu menulis dan mengap- likasikan metode pembelajaran yang tepat agar dapat memperbaiki hasil belajar siswa.

Metode pembelajaran sangat penting untuk mendukung proses pembelajaran. Pengertian Model pembelajaran dikemukakan oleh Rusman (2012:144) yaitu suatu rencana yang dapat digunakan untuk membentuk 
kurikulum, merancang bahan pembelajaran, dan membimbing pembelajaran di kelas atau yang lain. Ada beberapa metode pembelajaran yang dapat digunakan oleh seorang guru dalam pembelajaran, diantaranya metode Role Playing dan metode Brainstorming.

Metode adalah metode inovatif yang membuat siswa untuk aktif dalam mengeluarkan ide-ide yang kemudian disimulasikan oleh siswa dalam pembelajaran. Karakteristik metode Role Playing dan metode Brainstorming adalah siswa mengetahui bagaimana suatu materi pembelajaran diimplementasikan dalam kehidupan nyata dan siswa dituntut untuk mengeluarkan ide-ide tanpa adanya batasan berkreasi, serta menumbuhkan rasa percaya diri dan tanggungjawab siswa dalam menghadapi dunia kerja nantinya. Keunikan metode pembelajaran tersebut yang membuat peseta didik tertarik dan proses pembelajaran menjadi menyenangkan. Oleh karena itu, siswa lebih mudah menyerap dan memahami materi yang diajarkan sehingga dapat memperbaiki hasil belajarnya.

Metode Role Playing menurut Hamdayana (2015:189) merupakan cara untuk memahami bahan-bahan pelajaran melalui pengembangan imajinasi dan penghayatan siswa. Pengembangan imajinasi dan penghayatan tersebut dilakukan siswa dengan memerankannya sebagai tokoh hidup atau benda mati. Permainan ini biasanya dilakukan secara berkelompok, hal itu tergantung kepada apa yang dimainkan atau diperankan.

Artinya dalam cara penyampaian pembelajarannya yaitu ketika proses pembelajaran siswa diberi peran yang sesuai dengan masalah-masalah yang akan ajarkan, mendeskripsikan watak/karakter, dan menyiapkan segala sesuatu yang dibutuhkan oleh para pemain, sehingga dengan model tersebut diharapkan siswa aktif dalam pelajaran. Sedangkan metode pembelajaran Brainstorming menurut Suprijanto (2009:122) menyatakan bahwa metode Brainstorming merupakan salah satu bentuk berpikir kreatif sehingga pertimbangan memberikan jalan untuk berinisiatif kreatif".

Brainstorming berbeda dengan diskusi. Diskusi menekankan pada gagasan seseorang yang dapat ditanggapi (dilengkapi, dikurangi didukung, tidak disepakati) oleh peserta yang lain. Sedangkan brainstorming menitikberatkan pada pendapat orang lain namun tidak untuk ditanggapi. Metode ini berdasarkan pendapat bahwa setiap kelompok dapat mengusulkan lebih banyak gagasan dari anggotanya masingmasing.

Dalam metode ini disediakan beberapa soal. Lalu para peserta diajukan untuk menyampaikan ide mengenai soal tersebut, tidak peduli seaneh apapun idenya, ide tersebut tidak ditolak secara langsung, namun dianalisis terlebih dahulu, disintesis dan dievaluasi. Boleh jadi solusi yang muncul adalah solusi yang tidak terduga.

Dengan menggunakan model atau metode yang menarik dalam pembelajaran memungkinkan dapat meningkatkan dan memperbesar minat belajar siswa. Apabila siswa merasa senang dan terbawa suasana pada model dan metode pembelajaran yang dibawakan oleh guru, hal tersebut dapat menjadikan hasil belajar siswa meningkat. Demi tercapainya tujuan serta kelancaran dalam proses belajar mengajar guru bertanggung jawab selama proses belajar mengajar berlangsung, oleh karena itu metode pembelajaran adalah bagian dari faktor yang dapat memperbaiki dan meningkatkan hasil belajar siswa secara optimal.

\section{METODE PENELITIAN}

Penelitian ini menggunakan Metode Eksperimen (Quasi Experimental) dengan design Nonequivalent Control Group Design. Dalam design ini penelitian dibagi menjadi dua kelas, yakni kelas eksperimen yang menggunakan metode Role Playing dan kelas kontrol yang menggunakan metode Brainstorming. Design tersebut dapat digambarkan sebagai berikut:

Tabel 2

Dedsain Penelitian

Kelas Test Awal Treatment Test Akhir

\begin{tabular}{lccc}
\hline Eksperimen & $\mathrm{O}_{1}$ & $\mathrm{X}$ & $\mathrm{O}_{2}$ \\
Kontrol & $\mathrm{O}_{3}$ & - & $\mathrm{O}_{4}$ \\
\multicolumn{2}{l}{ Sugiyono (2018:79) } & &
\end{tabular}


Sampel diambil sebanyak 29 orang terdiri dari 15 orang dari kelas XI AKL 1 sebagai kelas eksperimen dan 14 orang dari kelas XI AKL 2 sebagai kelas kontrol. Teknik pengumpulan data yang dilakukan dalam penelitian ini melalui observasi, dokumentasi, wawancara dan tes. Selanjutnya data dihitung dan dianalisis untuk menjawab hipotesis.

Hipotesis penelitian:

1. Ha diterima dan Ho ditolak jika nilai thitung $>$ dari nilai ttabel artinya terdapat perbedan hasil belajar siswa yang menggunakan metode Role Playing.

2. Ho diterima dan Ha ditolak jika nilai thitung $<$ dari nilai ttabel artinya tidak terdapat perbedan hasil belajar siswa setelah menggunakan metode Role Playing.

\section{HASIL DAN PEMBAHASAN}

\section{Hasil Belajar Siswa yang Menggunakan Metode Role Playing Pada Pengukuran Awal dan} Pengukuran Akhir

Hasil belajar siswa yang menggunakan metode Role Playing mata pelajaran akuntansi kompetensi dasar siklus akuntansi perusahaan dagang pada pengukuran awal (posttest) dan pada pengukuran akhir (posttest) dilihat dari data hasil pretest dan posttest sebagai berikut.

Tabel 3

Data Hasil Pretest dan Posttest Kelas Eksperimen

\begin{tabular}{ccc} 
No & Pretest & Posttest \\
\hline 1 & 80 & 85 \\
2 & 45 & 75 \\
3 & 80 & 90 \\
4 & 75 & 75 \\
5 & 75 & 85 \\
6 & 80 & 85 \\
7 & 70 & 75 \\
8 & 70 & 90 \\
9 & 80 & 85 \\
10 & 45 & 70 \\
11 & 65 & 80 \\
12 & 70 & 95 \\
13 & 65 & 85 \\
14 & 65 & 75 \\
15 & 70 & 90 \\
$\sum$ & 1035 & 1240 \\
\hline Rata-rata & 69,00 & 82,67 \\
Nilai Terendah & 45 & 70 \\
Nilai Tertinggi & 80 & 95
\end{tabular}

Berdasarkan hasil perhitungan perbedaan hasil belajar siswa diperoleh nilai rata-rata hasil belajar di kelas eksperimen yang menggunakan metode Role Playing pada pengukuran awal (pretest) diperoleh nilai rata-rata sebesar 69,00 dan pada pengukuran akhir diperoleh nilai ratarata sebesar 82,67 sehingga diperoleh selisih sebesar 13,67 jika diprosentasikan sebesar $16,54 \%$ dengan standar deviasi masing-masing sebesar 10,83 dan 7,04. Dari perhitungan diperoleh nilai thitung sebesar 4,11 hasil tersebut kemudian dibandingkan dengan nilai ttabel sebesar 1,70 dengan taraf kepercayaan
$95 \%$ atau taraf signifikansi 0,05 serta derajat kebebasan (dk) sebesar 27 sehingga nilai thitung $>$ dari nilai ttabel atau 4,11 > dari 1,07. Dengan demikian hasil perhitungan menunjukan bahwa terdapat perbedaan yang signifikan pada hasil belajar siswa yang menggunakan metode role playing dari pengukuran awal ke pengukuran akhir.

Hal tersebut bahwa penerapan metode role playing dalam proses pembelajaran, siswa menjadi lebih aktif, berani, dan kreatif dalam memecahkan masalah serta dengan adanya kegiatan berinteraksi secara langsung dengan 
teman sesamanya akan mendorong siswa untuk berbagi pendapat, hal tersebut akan menambah pengetahuan yang dimiliki siswa sehingga hasil belajar yang diperoleh menjadi lebih baik dan optimal.

\section{Hasil Belajar Siswa yang Menggunakan Metode role playing (Kelas Eksperimen) dengan yang Menggunakan Metode Brainstorming (Kelas Kontrol)}

Hasil belajar siswa yang menggunakan metode role playing (kelas eksperimen) dengan yang menggunakan metode pembelajaran Brainstorming (kelas kontrol) mata pelajaran akuntansi kompetensi dasar siklus akuntansi perusahaan dagang pada pengukuran akhir (posttest) penulis melakukan perhitungan dengan langkah-langkah berdasarkan hasil posttest di kelas eksperimen dan hasil posttest di kelas kontrol sebagai berikut:

Tabel 4

Data Hasil Posttest Kelas Eksperimen dan Kelas Kontrol

\begin{tabular}{ccc}
$\mathbf{N}$ & $\begin{array}{c}\text { Posttest } \\
\text { Eksperimen }\end{array}$ & $\begin{array}{c}\text { Posttest } \\
\text { Kontrol }\end{array}$ \\
\hline 1 & 85 & 75 \\
2 & 75 & 70 \\
3 & 90 & 85 \\
4 & 75 & 70 \\
5 & 85 & 75 \\
6 & 85 & 85 \\
7 & 75 & 70 \\
8 & 90 & 80 \\
9 & 85 & 75 \\
10 & 70 & 80 \\
11 & 80 & 80 \\
12 & 95 & 85 \\
13 & 85 & 75 \\
14 & 75 & 80 \\
15 & 90 & - \\
$\sum$ & 1240 & 1085 \\
\hline Rata-rata & 82,67 & 72,33 \\
Nilai Terendah & 70 & 70 \\
Nilai Tertinggi & 95 & 85
\end{tabular}

Berdasarkan hasil pengujian hipotesis diketahui bahwa metode role playing yang diterapkan di kelas eksperimen lebih unggul dan menghasilkan nilai akhir yang lebih tinggi dibandingkan dengan metode pembelajaran Brainstorming pada kelas kontrol. Hal ini dibuktikan dengan nilai rata-rata posttest pada kelas eksperimen sebesar 82,67 sedangkan pada kelas kontrol sebesar 77,50 sehingga diperoleh selisih sebesar 5,17 jika diprosentasikan sebesar $6,25 \%$ dengan standar deviasi masing-masing sebesar 7,04 dan 5,26. Dari perhitungan diperoleh nilai thitung sebesar 2,25 hasil tersebut kemudian dibandingkan dengan nilai ttabel sebesar 1,70 dengan taraf kepercayaan
95\% atau taraf signifikansi 0,05 serta derajat kebebasan (dk) sebesar 27 sehingga nilai thitung $>$ dari nilai ttabel atau 2,25 $>$ dari 1,07. Dengan demikian hasil perhitungan menunjukan bahwa adanya perbedaan yang signifikan pada hasil belajar siswa pada pengukuran akhir (posttest) yang menggunakan metode role playing dibandingkan dengan yang menggunakan metode Brainstorming.

Berdasarkan hasil pengujian dapat disimpulkan bahwa metode role playing lebih unggul dalam meningkatkan hasil belajar siswa daripada metode pembelajaran Brainstorming. Meskipun kedua tipe ini melibatkan siswa menjadi lebih aktif dalam kegiatan belajar, 
namun metode role playing lebih unggul dikarenakan metode role playing tidak hanya memfokuskan pembelajaran yang berbasis pada guru, siswa aktif dan bertanggung jawab atas apa yang mereka kerjakan, siswa juga tidak merasa terbebani kesalahan pada pendidik tetapi dibebani rasa agar tidak terjadi kesalahan pada perusahaan yang mereka kerjakan. Metode role playing juga mencoba membuat materi akuntansi menjadi mudah dipahami karena dikerjakan bersama dan dalam kondisi yang mendekati dunia nyata, selain itu untuk memenangkan sebuah game siswa terlebih dahulu harus belajar dalam kelompok untuk memahami materi yang telah disampaikan oleh guru. Dengan demikian dapat meningkatkan antusias dan dapat membuat siswa lebih senang dalam mengikuti kegiatan pembelajaran.

Dengan demikian metode role playing merupakan cara belajar kelompok yang mampu meningkatkan rasa kerjasama antar kelompok dan siswa lebih dominan aktif sedangkan guru hanya sebagai fasilitator, sedangkan metode pembelajaran Brainstorming siswa hanya aktif dalam mengeluarkan pendapatnya tanpa dikomentari oleh siswa lainnya.

\section{Pengujian Hipotesis}

Hipotesis yang diuji adalah:

a. Ha diterima dan Ho ditolak jika nilai thitung $>$ dari nilai ttabel artinya terdapat perbedan hasil belajar siswa yang menggunakan metode role playing.

b. Ho diterima dan $\mathrm{Ha}$ ditolak jika nilai thitung $<$ dari nilai ttabel artinya tidak terdapat perbedan hasil belajar siswa setelah menggunakan metode role playing.

\section{PENUTUP}

Berdasarkan pembahasan yang penulis sajikan, dapat ditarik beberapa simpulan sebagai berikut:

1. Perbedaan hasil belajar siswa pada pengukuran awal (Pretest) dan pengukuran akhir (Posttest) mata pelajaran akuntansi kompetensi dasar siklus akuntansi perusahaan dagang yang menggunakan metode role playing mengalami peningkatan. Artinya metode role playing meningkatkan hasil belajar siswa pada mata pelajaran akuntansi di SMK Negeri 3 Banjar.

2. Perbedaan hasil belajar siswa pada pengukuran akhir (Posttest) yang menggunakan metode role playing lebih unggul dibandingkan dengan hasil belajar siswa yang menggunakan metode pembelajaran Brainstorming. Artinya penerapan metode role playing lebih efektif dibandingkan dengan metode pembelajaran Brainstorming pada mata pelajaran akuntansi di SMK Negeri 3 Banjar.

\section{DAFTAR PUSTAKA}

Arifin, Zainal. 2013. Evaluasi Pembelajaran. Bandung: Remaja Rosdakarya.

Arikunto, Suharsimi. 2010. Prosedur Penelitian: Suatu Pendekatan Praktik (Edisi Revisi 2010). Jakarta: Rineka Cipta.

Arikunto, Suharsimi. 2012. Dasar-Dasar Evaluasi Belajar. Jakarta: Bumi Aksara.

Arikunto, Suharsimi. 2013. Prosedur Penelitian: Suatu Pendekatan Praktik. Jakarta: Rineka Cipta.

Aqib, Zainal. 2015. Model-Model, Media, dan Strategi Pembelajaran Kontekstual (Inovatif). Bandung: Yrama Widya.

Aunurrahman. 2013. Belajar dan Pembelajaran. Bandung: Alfabeta.

Baharudin, dkk. 2007. Teori Belajar dan Pembelajaran. Yogyakarta: Ar-Ruzz Media.

Dahar, Ratna Wilis. 2011. Teori-Teori Belajar dan Pembelajaran. Jakarta: Erlangga.

Darmadi, Hamid. 2010. Metode Penelitian Pendidikan. Bandung: Alfabeta.

Fatturohman, Pupuh dan M. Sobry Sutikno. 2011. Strategi Belajar Mengajar. Bandung: Refika Aditama.

Jamil, Suprihatiningrum. 2013. Strategi Pembelajaran. Yogyakarta: Ar-Ruzz Media.

Karim, Abdul. 2017. Penerapan Metode Brainstorming Pada Mata Pelajaran IPS untuk Meningkatkan Hasil Belajar Kelas VIII di SMPN 4 Rumbio Jaya. (Online). (Jurnal Pendidikan Ekonomi Akuntansi FKIP UIR Vol 5 No 1 Tahun 2017 ISSN: 2337-652x).

Kurniawan, Deni. 2014. Pembelajaran Terpadu Tematik ( Teori, Praktik, dan Penilaian). Bandung: Alfabeta.

Halimah, Siti Nur. 2017. Penerapan Model Role Playing dengan Metode Brainstorming untuk Meningkatkan Hasil Belajar padaPembelajaran Akuntansi Kelas XI SMKN 1 Surakarta. (Online). (Jurnal Pendidikan Akuntansi Universitas Sebelas Maret Vol 3 No 1 Tahun 2017). 
Hamdayana, Jumanta. 2015. Model dan Metode Pembelajaran Kreatif dan Berkarakter. Bogor: Ghalia Indonesia.

Hanafiah, Nanang dan Cucu Suhana. 2012. Konsep Strategi Pembelajaran. Bandung: Refika Aditama.

Ismiah, Lia. 2016. Efektivitas Metode Role Playing Terhadap Keterampilan Berbicara Siswa pada Mata Pelajaran Bahasa Indonesia Kelas XI SMA Muhammadiyah Pakem Sleman. (Online). (http://journal.student.ac.id).

Luthfiyati. 2011. Model Pembelajaran Osborn Untuk Meningkatkan Kemampuan Pemecahan Masalah Matematis Siswa. (Online).

Tersedia:http://www/te2hicacu.files.word press.com/2011/12artikel.docx. [akses: Februari 2015].

Mulyono, Nono. 2016. Kurikulum dan Pembelajaran. Bandung: Rizqi Press.

Purwanto, Ngalim. 2007. Psikologi Pendidikan. Bandung: Remaja Rosdakarya.

Roestiyah. 2012. Strategi Belajar Mengajar. Jakarta: Rineka Cipta.

Rusman. 2012. Model-Model Pembelajaran Mengembangkan Profesionalisme Guru. Jakarta: Rajawali Pers.

Salahudin, Anas dan Irwanto Alkrienciehie. 2013. Pendidikan Karakter. Bandung: Pustaka Setia.

Sani, Ridwan Abdullah. 2013. Inovasi Pembelajaran. Jakarta: Bumi Aksara.

Slameto. 2010. Belajar dan Faktor-faktor yang Mempengaruhinya. Jakarta: Rineka Cipta.

Sudjana, Nana. 2012. Penelitian Hasil Proses Belajar Mengajar. Bandung: Remaja Rosdakarya.

Sudjana, Nana. 2016. Penelitian Hasil Proses Belajar Mengajar. Bandung: Remaja Rosdakarya.

Sugiyono. 2018. Metode Penelitian Kuantitatif, Kualitatif, dan R\&D. Bandung: Alfabeta.

Suprijanto. 2009. Pendidikan Orang Dewasa. Jakarta: Bumi Aksara. 
